Subscriptions: Annual subscription rates for Volume 29 (2014) [April, August, December]: Institutional subscription rates, print and online: US $\$ 143.00$ in the USA, Canada, and Mexico; UK $104.00+$ VAT elsewhere. Institutions, only only: US $\$ 135.00$ in the USA, Canada and Mexico; UK $£ 98.00$ + VAT elsewhere. Institutional subscription correspondence and address changes should be sent to: Cambridge University Press, 100 Brook Hill Drive, West Nyack, NY 10994, USA, email subscriptions_newyork@cambridge.org, for customers in the USA, Canada, or Mexico. Customers elsewhere should contact: Cambridge University Press, The Edinburgh Building, Shaftesbury Road, Cambridge CB2 8RU, UK, email journals@cambridge.org.

Abbonement: Prix de l'abonnement annuel au volume 29 (2014) [avril, août, décembre]: abonnement institutionnel, version impriméeeten ligne: 143 \$ USauxÉtats-Unis, au Canadaetau Mexique;104 GBP+TVA pour les autres pays. Institutionnel, en ligne seulement: 135 \$ US aux États-Unis, au Canada et au Mexique; 98 GBP + TVA pour les autres pays. Prière d'envoyer toute correspondance relative aux abonnements institutionnels et les changements d'adresse à Cambridge University Press, 100 Brook Hill Drive, West Nyack, NY 10994, USA, adresse électronique subscriptions_newyork@cambridge.org, pour les clients résidant aux États-Unis, au Canada et au Mexique. Les clients d'autres pays sont priés d'utiliser I'adresse: Cambridge University Press, The Edinburgh Building, Shaftesbury Road, Cambridge CB2 8RU, UK, adresse électronique journals@cambridge.org.

Canadian Law and Society Association: Membership in the Canadian Law and Society Association includes an individual subscription to the journal. To find out how to become a member please visit http://acds-clsa.org/en/subscribe.cfm

Association canadienne droit et société: La cotisation versée à l'Association canadienne droit et société donne droit à un abonnement individuel à la revue. Pour devenir member veuillez svp visiter http://acds-clsa.org/fr/subscribe.cfm

Permissions information: All rights reserved. No part of this publication may be reproduced, in any form or by any means, electronic, photocopying, or otherwise, without permission in writing from Cambridge University Press. Policies, request forms and contacts are available at: http://journals.cambridge.org/action/ rightsAndPermissions Permission to copy (for users in the USA) is available from Copyright Clearance Center http://www.copyright.com, email info@copyright.com.

Information sur les permissions: Tous droits réservés. La reproduction de cette publication, en partie comme en entier, n'est autorisée sous aucune forme ou aucun moyen, électronique, photocopié ou autre, sans la permission écrite de Cambridge University Press. Pour plus d'informations, les formulaires de demande et les coordonnées nécessaires, rendez-vous à l'adresse web suivante:

http://journals.cambridge.org/action/rightsAndPermissions Le droit de copie (pour les utilisateurs aux Etats-Unis) peut être autorisé par le Copyright Clearance Center http://www.copyright.com, email info@ copyright.com.

Advertising: To advertise in the journal email USAdSales@cambridge.org or telephone +1 (212) 337 5053 in the USA, Canada or Mexico; email ad_sales@cambridge.org or telephone +44 (1223) 325083 in the rest of the world.

Publicité: Pour publicité dans la revue adresse électronique USAdSales@cambridge.org ou téléphone +1 (212) 3375053 pour les clients résidant aux États-Unis, au Canada et au Mexique; adresse électronique ad_sales@cambridge.org ou téléphone +44 (1223) 325083 pour les clients d'autres pays. 
Stephanie Ben-Ishai and Saul Schwartz

Credit Counselling in Canada: An Empirical Examination

Ronald Niezen and Marie-Pierre Gadoua

Témoignage et histoire dans la Commission de vérité et de réconciliation du Canada

Hélène Belleau and Pascale Cornut St-Pierre

Conjugal Interdependence in Quebec: From Legal Rules to Social Representations About Spousal Support and Property Division on Conjugal Breakdown

\section{Sarah Sorial}

Free Speech, Hate Speech, and the Problem of (Manufactured) Authority

David Koussens, Stéphane Bernatchez, et Marie-Pierre Robert

Le voile intégral: analyse juridique d'un objet religieux

\section{Bertrand Lavoie}

Écueils et objectifs partagés entre juristes et sociologues : Réflexions sur le dialogue interdisciplinaire entre le droit et la sociologie

Benjamin L. Berger

Religious Diversity, Education, and the "Crisis" in State Neutrality

Ngaire Naffine

Review Essay: The Liberal Legal Individual Accused:The Relational Case

\section{Book Reviews / Comptes-rendus}

